\title{
Equitable Development Movement: A Progressive Response to the Urban Redevelopment Landscape Nationwide and in Washington, DC's Shaw Community
}

\author{
By Liz Sablich
}

A contemporary urban renaissance is bringing new residents into cities across the United States and is spurring significant economic development in previously downtrodden urban communities. As dramatic change sweeps across America's cities, many of those communities' long-term, low-income residents of color are left out of the decision-making process by which their neighborhoods are transformed. This paper identifies the shortcomings of privatism - a prevalent practice in contemporary urban development which encourages local governments to rely on and to subsidize private enterprise. The paper further explores the merits of the equitable development movement as a progressive response to the failures of privatism to produce positive outcomes for vulnerable populations. Washington, DC's Shaw community serves as an example of America's changing urban landscape, and its community organization ONE DC provides a useful illustration of equitable development principles in practice.

\section{Introduction}

Urban development-generally understood as the work associated with improving the vitality of urban businesses and neighborhoods-is a diverse arena in which a wide range of industries and professionals are invested. From politicians and community organizers to real estate brokers and contractors, many different interests are at play in any given urban development project. Questions that inevitably arise out of such projects include: who benefits from such development, and who controls it?

The equitable development movement, embraced by community leaders nationwide, attempts to ensure that the answer to both questions is "long-term neighborhood residents." As defined by PolicyLink, an organization recognized for pioneering the equitable development movement, "[e]quitable development is an approach to creating healthy, vibrant, communities of opportunity" (PolicyLink 2012). The desired outcome of intentional equitable development activity is to ensure that low-income communities and communities of color participate in and benefit from decisions that shape their neighborhoods and regions.

Given the increased demands on land in many American cities stemming from a contemporary urban renaissance, as well as the pervasive power of market forces to shape development, it is essential that community organizers embrace equitable development concepts in order to protect and benefit the long-term lowincome residents of urban neighborhoods. This article will explore some of the trends currently facing those engaged in urban development initiatives and the threats 
that these trends pose to culturally-rich but financially-poor urban communities. Focusing on the Shaw neighborhood in Washington, DC and that community's ONE DC organization, this article will identify the strengths and shortcomings of the equitable development movement as a means to protect long-term residents in a changing neighborhood, and to ensure that they benefit from the private and public investment flooding into their community.

\section{Trends Affecting Contemporary Metropolitan America}

\section{Urban Renaissance}

Over the past decade and a half, many Americans have exhibited a growing preference for urban residence, marking a dramatic shift in the way they choose to live and work (Leinberger 2008). This shift is fueled by a contemporary popular culture that celebrates the city as a source of freedom, excitement, and artistic and cultural cache, which is manifested in skyrocketing demand and pricing in urban housing markets (Leinberger 2008). Indeed, "urban residential neighborhood space goes for 40 percent to 200 percent more than traditional suburban space in areas as diverse as New York City; Portland, Oregon; Seattle; and Washington, DC" (Leinberger 2008, 72).

This contemporary urban renaissance follows decades of urban decline, which began with the mid-twentieth century exodus of middle- and working-class Americans to the suburbs. Deterioration continued throughout the 1980s, as industrial cities persistently bled jobs and residents, and became increasingly perceived as dens of crime. But William Lucy, Professor of Urban and Environmental Planning at the University of Virginia, contends that a dramatic shift occurred during the 1990 s, and cities began attracting residents with money (Lucy 2010). Lucy points to a fondness for old homes as a partial explanation for this shift. In addition to the cultural cache associated with cities, Leinberger argues that a growing interest in sustainable and walkable communities is also responsible for the change (2008). Both authors, along with many others, such as Arthur C. Nelson, Director of the Metropolitan Institute at Virginia Tech, acknowledge that changing demographics of the American population have a major effect on where Americans choose to live (Nelson 2011). Young people today are marrying later and having fewer children than past generations, which allows more flexibility in their housing choices as they face fewer constraints based on square footage, neighborhood schools, or other factors important to families with children (Leinberger 2008). Indeed, by 2025 the United States will contain "about as many single-person households as families with children" (Leinberger 2008, 74).

True to this pattern of urban renaissance, Washington, DC saw a dramatic increase in population between the 2000 and 2010 census years. After 50 years of losing residents, the city grew more than 5 percent over the decade and sailed past 600,000 residents for the first time in a generation (Morello and Keating 2010). The almost 30,000 net residents gained was the largest spike DC had seen since the end of World War II, when the city had 802,000 residents (Morello and Keating 2010).

\section{Gentrification}

Among local political leaders, the city's population growth is considered a positive trend. A larger population means a larger tax base, and in many cases such growth is associated with improvements to the city's quality of life. However, dramatic and rapid change presents important challenges-most notably, gentrification. New wealthy residents move into the city, often settling in communities that have long been home to low-income minority populations. They are attracted by initially-reasonable housing prices, convenient central city locations, and opportunities for economic growth. Newer, wealthier residents 
can attract new investment and development, often on a large scale, which in turn attracts even more new residents.

Problems associated with gentrification include race relations characterized by mistrust, rising housing prices and cost of living expenses, whitewashing of neighborhood cultures, and, in many cases, the eventual displacement of minority populations. As one longtime resident of a gentrifying St. Paul, Minnesota neighborhood put it, "They [outsiders] are the ones buying up those houses at those ridiculous prices because they can afford them. It's an invasion of our space, so to speak" (Lucy 2010, 36).

\section{Privatism}

Municipal governments across the United States are keen to take advantage of this renewed interest in urban living and to promote revitalization or redevelopment projects that ensure their cities have attractive neighborhoods and homes to offer to a new tax base. Indeed, even before the urban renaissance began in the 1990s local governments were busy at work priming the pump for just such a time, investing in downtrodden parts of their cities by building sports arenas and entertainment destinations. Such activity has dramatically intensified over the past 20 years as governments and developers alike recognize the revenue and profit potential in even the most unlikely urban communities.

With major redevelopment underway in cities across the country, it has become clear, as argued by Timothy Barnekov and Daniel Rich of University of Delaware's College of Human Services, Education and Public Policy (CHEP), that "contemporary local economic development policies reflect an underlying commitment to privatism-to enhancing and enlarging the role of the private sector in urban regeneration" (1989, 212). Barnekov and Rich acknowledge that local urban economic development initiatives vary widely from city to city, but indicate the trend toward privatism emerged nationwide during the Reagan administration, when the role of the federal government in local urban development programs was reduced dramatically.

According to a Heritage Foundation summary of the Reagan budget, it was the position of that administration that the federal government should play no role in local economic development projects, but should instead create a tax and regulatory climate conducive to enterprise in which private and local government development efforts were more likely to succeed (Heritage Foundation 1985). As a result, cities were forced to become more "selfreliant in forming strategic partnerships with local private sectors" (Barnekov and Rich 1989, 212). By the late 1990s, states, counties, and cities were spending close to $\$ 50$ billion per year on private-public partnership programs, reflecting a deepening reliance on these partnerships, and thus the provision of public subsidies to private developers, to fuel economic growth (Gross 2005).

The historian Sam Bass Warner refers to this phenomenon (of public entities subsidizing private development projects) as the tradition of privatism. Warner argues that privatism ties the success of a city to the vitality of its private sector, virtually ensuring a public reliance on private institutions for urban redevelopment (Warner 1987). Given the limited resources of local municipal governments and the more robust resources of many private institutions, this approach to urban redevelopment may appear to be a sound solution. However, Barnekov and Rich clearly illustrate that one of the consequences of privatism on urban redevelopment is privileging private interests over community interests:

In the context of privatism, urban development is essentially a problem of local economic growth, and the source of that problem lies in the constraints that have 
been placed on private investment. It follows from this diagnosis that in any serious effort at urban regeneration, priority must be given to the needs of the private sector, and public resources must be focused on the creation and enhancement of private investment opportunities. (1989, 214)

Given this framing of social problems as economic problems, many social scientists and community organizers would likely accept privatism as an appropriate solution to urban ills if proven effective. Unfortunately, a wealth of literature demonstrates that public subsidy of private development projects in the name of urban economic development have done little, if anything, to help the residents of distressed communities who are promised a great deal at the onset of such partnerships (Peters and Fisher 2004; Barnekov and Rich 1989). Further, Barnekov and Rich concluded that all the fundamental assumptions underlying public-private partnerships are false or greatly exaggerated. Though a full discussion of these fallacies is beyond the purview of this article, one conclusion of particular importance is the fact that "communities will not necessarily capture the benefits from local economic development programs because of the leakage of jobs and investment across municipal boundaries" $(1989,227)$.

At the same time that social scientists are showcasing the failure of privatism to benefit communities in need, developers continue to pursue opportunities in urban centers, and local governments continue to embrace public-private partnerships. Why do cities continue to pursue such initiatives without proof of their efficacy? There are many potential explanations, but sociologists John Logan and Harvey Molotch propose one answer worthy of careful consideration. According to Logan and Molotch, for those who hold power, the city is seen as little more than a growth machine-a mechanism that can be used to increase aggregate revenue via rent and taxes and trap the resulting profit for those in the right position to benefit $(1987,50)$.

Logan and Molotch further contend that local elites use their financial and social capital to influence the political agenda in support of their common commitment to growth. When successful, these coalitions abjure any notion that local government has any role to play other than promoting economic growth. Given this view of local government, along with the financial constraints most cities face, local authorities have little option but to fulfill their part in the growth machine lest their city be ignored by private business altogether. The result is a nation of local governments that compete for business, advocate growth, and support the ideology of value-free development. Relegated to this role of growth machine champion, local authorities generally ignore the empirical evidence to the contrary and continue to pursue private partnerships in the hope that private-sector growth will create new jobs and new investments that benefit community residents. While new jobs and new investments may result, they likely do not benefit long-term residents.

\section{Equitable Development}

In response to the factors discussed above-the migration of new residents into central cities, the resulting gentrification, and the continued and growing role of privatism in urban redevelopmenta new movement has emerged to address the concerns associated with unrestrained development driven by commercial interests. The equitable development movement is built on four guiding principles: integration of people and place; reduction of local and regional disparities; meaningful participation; and promotion of triplebottom-line investments that benefit the business community, local families, and the sustainability of community resources, natural and human (Blackwell and Bell 
2005; Moulden and Squires 2012).

This approach recognizes the inevitable role of private enterprise in urban redevelopment projects, and promotes appropriate strategies to safeguard the interests of long-term residents in communities undergoing privately-driven change. In asking who benefits from the development, this approach ensures that the interests of low-income communities and communities of color are taken into account.

According to Angela Blackwell and Judith Bell of PolicyLink, the equitable development movement is anchored by the fair distribution of affordable and raciallyinclusionary housing (2005). PolicyLink and other organizations that support equitable development initiatives insist that the urban planning process actively consider and address challenges associated with development that racial minorities and low-income families face. The movement recognizes that, in light of current trends, when the redevelopment process is underway in a given community, the issue of dislocation will surface. PolicyLink therefore advocates for designing the development process "with that reality in mind, taking advantage of land and property that may be quite affordable at the beginning of the process, and integrating benefits for existing residents [which] will lead to equitable results" (Blackwell and Bell 2005, 295). PolicyLink promotes several tools and strategies, including inclusionary zoning, housing trusts, and transitoriented development to ensure that affordable housing development and distribution are integrated into development projects that can then result in geographic, class, and racial fairness.

\section{Community Benefits Agreements}

One of the most effective tools available to equitable development advocates is the community benefits agreement. A community benefits agreement is a contract between local community organizations and a developer proposing a particular land use within that community (Been 2010). In a typical community benefits agreement, community members agree to support proposed projects conditional on the developer providing benefits such as assurances of local jobs, affordable housing, and environmental improvements (Been 2005). Community benefits agreements ensure that development is equitable, benefits all members of the community, and contributes to a stronger local community with enhanced quality of life. In addition to supporting equitable outcomes, community benefits agreements also ensure the development process itself is more fair and inclusive than traditional market-driven growth by including residents in the process and treating the community as a valuable asset.

While the advantages that community benefits agreements contribute to the community are apparent, these types of agreements reward developers as well. Public support of a project can help ensure a smooth process for obtaining necessary permits and variances, and a supportive community may be more likely to patronize a new development. Developers also face risks for eschewing a proposed community benefits agreement. Community members may stage public demonstrations in opposition to the development, or actively recruit a more cooperative developer to petition the city for the right to take over the project.

Signed in 2001, the community benefits agreement between the developer of the Los Angeles Sports and Entertainment District and the Figueroa Corridor Coalition for Economic Justice (a coalition that represented more than 30 local community organizations), is widely considered the first significant and successful community benefits agreement in the United States. Some of the provisions of the Los Angeles Sports and Entertainment District Community Benefits Agreement included: a \$1 million developer-funded trust for the creation or improvement of parks and recreational facilities; a hiring 
program that targeted job opportunities to those displaced by the development as well as to low-income individuals residing within three miles of the project; job training programs coordinated with community groups; and a requirement that 20 percent of the residential units in the project be affordable, with 30 percent of those units reserved for families earning zero to 50 percent of the area median income, 35 percent reserved for families earning 51 to 60 percent, and 35 percent reserved for families earning 61 to 80 percent of the area median income (Figueroa Corridor Coalition for Economic Justice 2001). Similar provisions have become standard in community benefits agreements emerging nationwide in response to development projects.

\section{Shaw: A Case Study}

Washington, DC's Shaw neighborhood presents a microcosm of the complexities associated with contemporary urban redevelopment. Shaw is a neighborhood in the Northwest quadrant of Washington, DC that is bound by Florida Avenue NW and M Street NW on the north and south, and by North Capitol Street and 7th Street NW on the east and west, respectively (Khandhar 2006). Shaw is undergoing a "rapid metamorphosis fueled by real estate speculation and historical preservation initiatives" (Khandhar 2006, 25).

Shaw is a community rich with history. Named for Civil War Colonel Robert Gould Shaw, the neighborhood originated as a freed slave encampment just outside the original city limits. The neighborhood thrived in the nineteenth and early-twentieth centuries as a bastion of black culture-the pre-Harlem epicenter of black intellectual and artistic life in the United States (Beyond DC 2013). Howard University was chartered there in 1866 , bringing degree-seeking black men from across the United States to the neighborhood. Duke Ellington, Langston Hughes, and countless other black visionaries and successful black businesses called the area home during the 1920s, '30s, and '40s (Juskus and Elia 2007). However, as segregation began to ease throughout Washington, DC in the early 1960s, other residential areas became available to black families. As those with the financial means to relocate did so, Shaw suffered a steady economic and cultural decline. This deterioration was exacerbated by fears that "the steamroller of urban renewal would bear down on midcity [Shaw] and flatten yet another low-income, black neighborhood," as well as the 1968 riots following the assassination of Martin Luther King, Jr. (Juskus and Elia 2007). For decades following, vacant lots and storefronts defined the neighborhood.

In the early twenty-first century, however, investment returned to Shaw. Following successful redevelopment projects in neighboring communities (including Penn Quarter to the south and the U Street Corridor to the north), Washington, DC's municipal government launched the DUKE Plan in 2005 to guide revitalization efforts in Shaw. The plan was designed to attract new investment to Shaw by drawing from the area's rich cultural history, framing the area as a "cultural destination district" to highlight its historic significance as a vibrant African American cultural community (Khandhar 2006). In 2007, authors Ryan Juskus and Elizabeth Elia predicted, "[t]he commodification of early twentieth-century black culture, and the lure of prime, centralcity property, is a sure sign that gentrification will find its way to 7 th Street" (2007).

They were not wrong-today, developers in Washington, DC routinely and competitively seek property in Shaw. Additionally, the demographic makeup of Shaw has changed rapidly and dramatically. Between 2000 and 2010, the proportion of African Americans in Shaw decreased from 81 percent to 54 percent while the white population grew from 5 to 28 percent (US Census Bureau 2000, 2011). During this same period, the median household income in Shaw has risen 
from $\$ 28,363$ to $\$ 65,162$ (US Census Bureau 2000, 2011). Housing prices in Shaw, like Washington, DC more broadly, are rising: according to Standard \& Poor's, the housing market in the District has appreciated 83 percent between 2000 and 2010, more than any other American city (Abowd 2011).

As in many gentrifying neighborhoods, Shaw's longtime residents (including homeowners) have mixed reactions to the changes taking place around them. While some may appreciate rising home values and certain other developmentssuch as the Shaw-Howard U Metro Station that brought Metrorail service to the community in 1991, or the Watha T. DanielShaw Library that opened in 2010-they simultaneously worry about the longterm impact such change will have on the neighborhood and its residents. In a post on a local blog, a longtime Shaw resident shared her thoughts on the changes in her community:

My eyes have seen so many changes in the neighborhood. All of the buildings and people done changed. Now, they make us think that Shaw is going to be the next Georgetown. I guess that means that a lot of us will be pushed out. That may help the neighborhood, but it won't really help all of kids on the corners who don't have nothing. Don't matter it they are in Shaw or you move 'em somewhere else, they are still going to be hanging out on the corner with no opportunities. (People's District of D.C. 2011)

\section{ONE DC}

Recognizing the inevitable tides of change headed for Shaw in the early twenty-first century, Manna Community Development Corporation (Manna CDC) was founded in 1997 to bring community organizing, equitable development, popu- lar education, and resident-led policy advocacy to the community. Manna CDC was originally created as a subsidiary of Manna Inc-an organization that has worked to create and preserve affordable housing across Washington, DC since 1982.

In 2006, Manna CDC transitioned from an affiliate corporation of Manna Inc. to an independent community development corporation called Organizing Neighborhood Equity, or ONE DC. Today, ONE DC embraces the principles of the equitable development movement and provides a useful local example of how that movement can be harnessed to benefit long-term, low-income, and minority community members.

One of the guiding principles upon which ONE DC was founded was the desire to "build the capacity of longtime, low-income residents as well new wealthier ones to exercise their political rights ... and ensure that the values of equitable development and justice are exercised" (ONE DC "Performance Challenge" 2013). With this idea in mind, ONE DC consulted with PolicyLink and other advocacy research organizations nationwide and worked with a coalition of community groups in 2004 to devise a list of equitable development principles (e.g. affordable housing setasides, livingwage jobs, jobs for neighborhood residents, and space for local businesses) before any specific real estate developments were planned for the Shaw area (Juskus and Elia 2007). Recognizing that redevelopment was inevitable in Shaw, ONE DC came to view the neighborhood's vacant parcels of land as valuable assets that could afford community members the power to become drivers of change in their neighborhood (Juskus and Elia 2007).

\section{The Role of Place and People}

A longstanding debate in the field of community development is between "place-based" and "people-based" solutions to the challenges associated with concentrated poverty and community de- 
cline (Crane and Manville 2008). Many policymakers, academics, and community organizers advocate for one approach over the other, believing that efforts should be directed at either a distressed place or a distressed people.

ONE DC, however, emphasizes the vital role of both people and place in developing solutions to questions of urban development. While it is right to protect the history and culture of a place, ONE DC believes that development plans must also explicitly protect people. Thus, ONE DC rejects the notion that better built environments will necessarily result in better opportunities for longtime residents (Moulden, interview, 2012). The organization also explicitly rejects the principles underlying the tradition of privatism-the belief that a successful private sector necessarily benefits all community members.

As such, "ONE DC states that it is not interested solely in place-based development" (Khandhar 2006, 29). The organization emphasizes that simply creating new businesses, new housing, and new jobs will not automatically improve things for community residents. While ONE DC is not opposed to all development or to all new residents, it continues to fight for economic and racial equity by empowering long-term neighborhood residents to advocate for themselves and their community (Khandhar 2006).

According to ONE DC Resource Organizer Dominic Moulden, the only way that longtime residents of Shaw will benefit from economic development in the area is if they themselves have a hand in shaping employment, economic, and housing policy (Moulden, interview, 2012). To this end, ONE DC embraces community organizing and community-controlled development as the tools to achieve desirable and equitable outcomes (Khandhar 2006). ONE DC embraces popular education and tenant organizing as a means to achieve equitable development, ensuring that residents have a voice in the process. As Ryan Juskus and Elizabeth Elia state, "[t]his is the revolutionary idea ... that the community members-even those without money or power, who are usually ignored in development plans or manipulated like chess pieces-can be an asset and a force with which to contend" (2007).

With its initial list of equitable development principles and its commitment to ensuring that any place-based revitalization activities would explicitly benefit people as well, ONE DC hoped to set the standards for development projects throughout Shaw and the District as a whole. Thus, ONE DC approached the National Capital Revitalization Corporation, a publicly-chartered, privately-managed corporation created by the DC government to develop many of the city's vacant properties, in search of a partnership (Juskus and Elia 2007).

The National Capital Revitalization Corporation reflects Washington, DC's entrenched culture of privatism. According to the organization's website, its developments are accomplished through large-scale strategic business and real estate development partnerships that utilize public funding and support in order to leverage even larger sums of private capital, and it plays an influential role in DC development projects (National Capital Revitalization Corporation 2012). In early 2004, ONE DC proposed that its list of equitabledevelopment principles be included in the criteria that the National Capital Revitalization Corporation used to evaluate development proposals throughout the city (Juskus and Elia 2007). ONE DC's efforts did not have the intended impact, however, and the National Capital Revitalization Corporation declined to adopt the guiding principles. ONE DC had failed to ensure that equitable development principles were woven into the fabric of Washington, DC's neighborhood revitalization efforts.

\section{Community Benefits Agreement}

Despite its initial setback with the National Capital Revitalization Corporation, ONE DC continued to advocate for 
equitable development. When ONE DC learned in late 2004 that the National Capital Revitalization Corporation was negotiating plans for an undeveloped plot of land adjacent to the Shaw-Howard U Metro Station, known as Parcel 33, it drafted a community benefits agreement proposal specific to the pending deal based on its equitable development principles (Juskus and Elia 2007; DePillis 2010b). Advocating for social justice and threatening public protests if its proposal was not accepted, ONE DC succeeded in getting the National Capital Revitalization Corporation and private developers The Jarvis Company, Ellis Enterprises, and Four Points LLC to sign Washington, DC's first community benefits agreement in March 2005 (Juskus and Elia 2007; Collier 2011).

As Washington, DC's first community benefits agreement, this contract was a significant milestone. Specifics of the agreement included an affordable housing setaside, job training, employment opportunities, local business space, and a $\$ 750,000$ community development fund (Juskus and Elia 2007). Additionally, as part of the negotiations around Parcel 33 , the city agreed in a 2007 memorandum of understanding to include affordable rental housing at another neighboring site marked for future development, Parcel 42 (DePillis 2010b). This affordable housing was intended for residents making less than 50 percent of the area median income. It is important to note that neither the community benefits agreement nor the memorandum of understanding included explicit enforcement mechanisms.

Plans for the Parcel 33 development have undergone many changes since the community benefits agreement was signed in 2005. Popular urban radio franchiser Radio One had originally committed to purchasing a large portion of the development's commercial space and serving as the building's flagship tenant, but pulled out of the agreement in February 2010 citing cheaper real estate availability in the region (Gayle 2011; Krouse 2011). Despite this setback and a series of other delays, construction on the property began in late 2010. In 2011, the United Negro College Fund (UNCF) stepped in and purchased a 50,000-square-foot space for $\$ 23.87$ million, meeting the developer's need to secure a flagship anchor tenant. The DC City Council granted \$5.1 million in tax abatement and relocation assistance to support UNCF's decision to move its headquarters from Fairfax, VA (Sernovitz 2012). As part of the deal, UNCF was given naming rights to the Parcel 33 development site. In keeping with its commitment to serving the community, UNCF chose to name the complex Progression Place (Gayle 2011).

With a flagship tenant secured and construction nearly complete, Progression Place, which occupies an entire city block, is on the market and is expected to sell for more than \$130 million (Sernovitz 2012). Set for completion by the second quarter of 2013, Progression Place will include " 100,000 square feet of office space, a 205-unit apartment building, and more than 19,000 square feet of retail space" (Sernovitz 2012).

DC subsidies are responsible for \$20.33 million, or 14.5 percent, of Progression Place's price tag (Neibauer 2012). In addition to the assistance afforded to UNCF, the public subsidies include a \$2.7 million residential construction loan and a $\$ 13.23$ million infrastructure and parking space subsidy for the developer Four Points LLC (Neibauer 2012). Without the ONE DC community benefits agreement, this public investment would have come with absolutely no commitment that neighborhood or city residents would benefit from its sizable price tag.

In a nod to the area's growing economic vitality and private sector appeal, the Four Points LLC website proudly claims that the Progression Place property is "certain to become the cornerstone of DC's next great neighborhood." Should this prediction prove true, the stage will be set for countless development projects buttressed by millions of dollars in public 
subsidies. Without explicit intervention aimed at equitable development, these investments are unlikely to benefit longterm residents of the Shaw neighborhood.

\section{Lessons Learned}

It is yet to be seen whether the final Progression Place development will include all of the community benefits agreement provisions agreed upon in 2005, or whether the broader changes taking place in Shaw will have lasting positive outcomes for the long-term residents of the area. ONE DC has publicly stated that it intends to hold Progression Place accountable to the city's first community benefits agreement, to ensure that the agreed-upon 51 units of affordable housing actually go to DC residents, and to keep the community informed of how the $\$ 750,000$ community fund is utilized (ONE DC 2011). It is uncertain, however, how successful ONE DC will be in this endeavor, largely because the original community benefits agreement lacks built-in enforcement mechanisms or benchmarks for measuring the fulfillment of its guarantees.

ONE DC now recognizes three foundational elements missing from the Progression Place agreement that must be included in any future community benefits agreement to ensure its success: a compensatory damages clause in the case that the developer fails to uphold its end of the agreement; a clause that outlines liquidated damages that are to be paid directly to community members should any of the fundamental elements of the initial agreement (such as the area median income) change; and built-in compensation for a community oversight committee to monitor development and the fulfillment of the community benefits agreement, to be paid by the developer (Moulden, interview, 2012).

With construction set to conclude in 2013, ONE DC and the Shaw community will soon see the true impact of the Progression Place development and the result of the longstanding community benefits agreement. As of the fall of 2012, the development had employed 62 people, 45 of them Washington, DC residents, and the $\$ 750,000$ in community funds had been earmarked for a range of community initiatives, including afterschool programs and support for Shaw-based tenant organizations (Moulden and Squires 2012).

Other signs indicate that the community cannot expect full compliance with the original agreement. As mentioned previously, the community benefits agreement included a memorandum of understanding with the DC Council and the developers of Parcel 42 (Parcel 42 Partners, LLC), a lot neighboring Progression Place. In the memorandum of understanding, the city agreed that the development set for construction on Parcel 42 would include affordable housing set-asides (in exchange for being able to sell some of the Progression Place residential units at market rate). According to a 2010 Washington City Paper article, the parties agreed in 2007 to build 94 units of rental housing, all of which would be reserved for residents making less than 50 percent of area median income, with a certain number of units reserved for residents at various tiers of income (e.g. 10 percent, 20 percent, 30 percent of the area median income) (DePillis 2010a). In the memorandum of understanding, the District agreed to contribute $\$ 11.5$ million of the $\$ 28$ million budget for the project (2010a). Between 2007 and 2010, however, the city and Parcel 42 Partners, LLC scaled back their plans in order to make the project more financially and logistically feasible. The changes included scaling down from eight stories to five; reducing the number of apartments from 94 to 52 ; removing the stratified affordable housing setasides in favor of a universal cutoff at 50 percent of the area median income; and reducing the public subsidy from $\$ 11.5$ million to $\$ 6.5$ million (Hays 2010).

Following the announcement of these changes, community members, including ONE DC and local Advisory Neigh- 
borhood Commission officials, publicly voiced their disapproval of the revised development plan, which violated prior agreements (Hays 2010; Moulden, interview, 2012). With little public support for the project, the DC Office of the Deputy Mayor for Planning and Economic Development severed the deal entirely in 2011, ending the city's relationship with Parcel 42 Partners, LLC (DePillis 2011).

Still left with a vacant lot, the city placed the Parcel 42 property back up for development bids in April 2012 (Wilson 2012). Prior to the announcement, Washington City Paper's Lydia DePillis had predicted that "[t]his time around, the city isn't offering anything in subsidies besides free land, and can't make any promises about how affordable the apartments will be-very likely, developers will want to go as market rate as possible" (DePillis 2011). DePillis was correct. The city's 2012 request for expressions of interest regarding Parcel 42 required only that proposals include a "mixed income residential rental component maximizing the number of affordable housing units at or below 80 percent of Area Median Income" (Office of the Deputy Mayor for Planning and Economic Development 2012).

This turn of events is not at all what ONE DC had envisioned for the development of Parcel 42. Not only is the affordable housing requirement significantly weaker than originally agreed upon, it also fails to mandate tiered rent levels, meaning that rents will likely be priced well above the affordability of Shaw's lowestincome residents. Additionally, there are clear racial implications to the affordable housing clause as outlined in the request for expressions of interest, given the significant difference in black and white incomes in the community (Moulden, interview, 2012). In 2000, the median income for African American households in Shaw was less than half of the median income $(\$ 54,520)$ for white households in the community (Khandhar 2006). It is therefore extremely unlikely that many black residents of Shaw will be able to afford rents that are set to correspond to 80 percent of the area median income (Moulden, interview, 2012). By 2012, the area median income in Shaw for a oneperson household had risen to $\$ 75,250$ (Office of the Deputy Mayor for Planning and Economic Development 2012). Of that area median income, 80 percent is equal to $\$ 60,200$, nearly three times the median income for African American households in Shaw in 2000. It is clear that the affordable housing requirements in the Parcel 42 request for expressions of interest are unlikely to benefit Shaw's long-term residents of color.

ONE DC's Dominic Moulden considers the city's change of course on the Parcel 42 development a sign of greater challenges to come. Looking ahead at the future of Shaw, Moulden believes that ONE DC will be forced to wage an uphill battle in the interest of equitable development. "If the DC government has its way in the next five to ten years in the area between 7 th and U Street and 7th and Massachusetts Avenue, they would love for all the affordable housing in those blocks to disappear," claims Moulden. "Our vision is to see any new developments have jobs, housing, and education attached for low income residents and particularly African Americans" (Moulden, interview, 2012).

\section{A Response to the Tradition of Privatism}

ONE DC's early efforts, including its first community benefits agreement, were not perfect, but the organization has learned from its experiences and discovered ways to fine tune its implementation of equitable development principles. When executed properly and on a sufficient scale, these equitable development activities provide an effective response to the ubiquitous tradition of privatism that dominates urban development activity nationwide, often at the expense of urban residents (Logan and Molotch, 1987; Barnekov and Rich, 1989). Washington, DC is no exception, and the Progression 
Place project provides a useful illustration of the city's private public partnership approach to development.

Without the ONE DC community benefits agreement attached to the Progression Place project, over $\$ 20$ million of public money would have been invested with no assurance that neighborhood or city residents would benefit. As the literature suggests, cities continue to pursue private public partnerships in the name of economic development despite evidence that such projects often fail to benefit residents (Barnekov and Rich, 1989; Peters and Fisher, 2004). In the case of Progression Place, the Council of the District of Columbia provided substantial subsidies despite concerns that a development anchored by a nonprofit organization, apartments, and small retail outlets would not be able to quickly generate tax revenue to match the initial investment (Neibauer 2012). Certainly it can be argued that the benefits of the Progression Place development are not captured solely by its tax revenue. But many researchers, including Barnekov and Rich, have concluded that such public investment in private development rarely benefits neighborhood residents in the anticipated ways (1989). The ONE DC community benefits agreement, then, appears to be the only visible force attempting to ensure that long term Shaw residents stand to benefit from this multi million dollar investment.

If privatism is to continue influencing, if not dominating, economic development in American cities, then community partners must respond accordingly to ensure that public money is not spent at the expense of an area's long term residents. Through community benefits agreements and other equitable development initiatives, community organizations can help to shape the impact of public investment in their neighborhood in more progressive directions.

\section{Implications}

The realities facing the Shaw com- munity, residents, and ONE DC, suggest three major conclusions regarding urban revitalization. First, the equitable development movement is uniquely suited to address the complex challenges associated with contemporary urban redevelopment. The movement is responsive to the realities of the tradition of privatism that dominates local governance today-it recognizes that private investment is necessary to revitalization, but also believes that traditional market forces alone will not solve the social problems that often result from such investment. By focusing specifically on issues of race, class, and sustainability, the equitable development movement forces cities and developers to anticipate the dislocation that accompanies gentrification and to pursue development in a way that protects and benefits residents (particularly low income, minority residents) without sacrificing business interests. From a policy perspective, therefore, it is essential that more community organizations advocate for, and more city governments embrace, equitable development principles and strategies to shepherd development that is more racially and economically inclusive, and more broadly sustainable.

Additionally, in order to fully harness this unique power of equitable development principles, community organizations must develop more stringent community benefits agreements that specify damages to be awarded to the community if the agreement is not upheld. Of course, such agreements will be more challenging to secure, but as community benefits agreements become more prevalent throughout the city and the country, community organizations will gain more social, economic, and political capital to leverage benefits in negotiations and incentivize developers to accept stricter terms. Therefore, organizations currently utilizing community benefits agreements have a strong reason to advocate for others to adopt the tool as well.

Finally, the experiences of ONE 
DC suggest that the Washington, DC government, and perhaps other metropolitan local governments as well, are missing a valuable opportunity to regain some degree of control over development in their jurisdiction by not fully embracing and enforcing community benefits agreements. For many decades, local governments have been all but forced to play the role of private market champion in the urban growth machine (Logan and Molotch 1987). Community benefits agreements, however, provide such governments with a tool to ensure that public funding has some positive impact on community residents. City governments should consider ways in which they can play a more active role in promoting community benefits agreements. For example, cities might give greater weight to development proposals that include a community benefits agreement. Rather than be held hostage to the demands of developers, governments can enter meaningful partnerships with such entities, ensuring a greater return on public investment and creating a stronger, more inclusive local economy in the process.

\section{Conclusion}

The lasting impact of twenty-first century development in the Shaw community and of ONE DC's efforts to enable Shaw's long term low income residents to remain in their neighborhood and reap the benefits of its revitalization are yet to be seen. The contemporary landscape of urban redevelopment suggests, however, that the time is ripe for the equitable development movement to meaningfully impact the way in which urban communities are redeveloped in the United States. If
ONE DC and other community organizations continue to apply equitable development principles, develop ever stronger community benefits agreements, and find a way to extract deeper cooperation from the city government, it is likely that Shaw's rich cultural history, which is reflected in its buildings as well as its people, will be protected.

The newly renovated Howard Theatre, a historic landmark that helped launch the careers of Duke Ellington and Ella Fitzgerald before its façade and interior fell into disrepair, is once again a thriving cornerstone of the neighborhood, suggesting that the city's DUKE plan has been successful in its efforts to capitalize on the artistic history of this community. The line of patrons outside the door on a recent Saturday night-a group comprised of old and young, black and white-provides reason to believe that perhaps the efforts of ONE DC and other community advocates will succeed in ensuring that such renovations are not completed at the expense or the exclusion of long term residents.

As American cities struggle with the often conflicting interests of private business and community residents, organizations and governments across the country may benefit from examining the experiences of ONE DC, the challenges the organization has encountered, and the context in which it is attempting to promote equitable development. By doing so, community leaders will be better equipped to respond to change taking place in their communities and leverage that change as a vehicle by which to deliver equitable outcomes to their constituents.

\section{References}

Abowd, Paul. 2011. "Rising values for D.C. housing, but who can afford it?" American Observer, October 25. Accessed January 15, 2013. http://wp11.americanobserver.net/2011/10/dc-housing-values-rise-but-who-can-afford-it/.

Barnekov, Timothy and Daniel Rich. 1989. "Privatism and the Limits of Local Economic Development Policy," Urban Affairs Quarterly 25 (2): 212-238.

Been, Vicki. 2010. "Reassessing the State and Local Government Toolkit: Community 
Benefits Agreements: A New Local Government Tool or Another Variation on the Exactions Theme?" University of Chicago Law Review 77: 5.

Beyond DC. 2013. "Shaw, DC. The Original Harlem.” Accessed January 13, 2013. http:// beyonddc.com/profiles/shaw.shtml.

Blackwell, Angela Glover and Judith Bell. 2005. "Equitable Development for a Stronger Nation: Lessons from the Field.” The Geography of Opportunity. Washington: The Brookings Institution.

Crane, Randall and Michael Manville. 2008. "People or Place? Revisiting the Who Versus the Where of Urban Development.” Lincoln Institute of Land Policy Land Lines, July: 1-6.

Collier, Julie Ann. 2011. "CBAs as Mechanisms for Historic Preservation Planning and Implementation.” MS diss., Ball State University. Accessed March 14, 2013. http://www.google.com/url?sa=t\&rct=j\&q=\&esrc=s\&source=web\&cd=4\&ved =oCEoQFjAD\&url=http\%3A\%2F\%2Fcardinalscholar.bsu.edu\%2Fbitstream\%2 F123456789\%2F194731\%2F1\%2FCollierJ_2011-2_BODY.pdf\&ei=MyJCUaHr AaXC4APZiYHADw\&usg=AFQjCNFqdT6uuDaCOowcIZYq2oU-h7_1Ag\&sig2= ugnYdXcOrhPZtu_Y9OQOFA\&bvm=bv.43287494,d.dmg.

DePillis, Lydia. 2010a. "Community Leaders Reject Dramatically Scaled-Back Plans for 7th and R." Washington City Paper, June 3.

- - . 2010b. "Tent City on a Hill: What Will the Fight for Parcel 42 Achieve?" Washington City Paper, July 16.

---. 2011. "Another Chunk of City Land Back Up For Grabs: 7th and Rhode Island" Washington City Paper, September 7.

Figueroa Corridor Coalition for Economic Justice. 2001. Community Benefits Agreement. May 31. Accessed March 14, 2013. http://www.saje.net/atf/cf/\%7B493B2790DD4E-4EDo-8F4E-C78E8F3A7561\%7D/communitybenefits.pdf.

Four Points LLC. 2012. Accessed April 27, 2012. www.progressionplace.com.

Gayle, Anna-Lysa. 2011. "Progression' Coming to Shaw-Howard Metro.” The Hill Top, February 16.

Gross, Julian. 2005. "Community Benefits Agreements: Making Development Projects Accountable.” Good Jobs First. Accessed January 15, 2013. http://www.goodjobsfirst.org/sites/default/files/docs/pdf/cba2005final.pdf.

Hays, Brooks Butler. 2010. "Protesters Break Ground Before Developers at Parcel 42.” DC Mud, July 17. Accessed January 15, 2013. http://dcmud.blogspot. com/2010/o7/protesters-break-ground-before.html.

Heritage Foundation. 1985. "A Guide to the Reagan Budget." February 11. Accessed January 15, 2013. http://s3.amazonaws.com/thf_media/1985/pdf/bg408.pdf.

Juskus, Ryan and Elizabeth Elia. 2007. "Long Time Coming.” NHI Shelterforce, Summer.

Khandhar, Parag. 2006. "Where the Streets Have Many Names: Zoning, Community Power, and the Future of Shaw, Washington, D.C." The Modern American, Summer. 25-31.

Krouse, Sarah. 2011. "Radio One signs Silver Spring leases for HQ move." Washington Business Journal, July 25.

Leinberger, Christopher B. 2008. "The Next Slum?” The Atlantic, March.

Logan, John and Harvey Molotch. 1987. "The City as a Growth Machine," from Urban Fortunes, Berkeley: University of California Press.

Lucy, William H. 2010. "What Income Reveals," Foreclosing the Dream. Chicago: American Planning Association. 
Morello, Carol and Dan Keating. 2010. "D.C. population soars past 600,00o for first time in years." The Washington Post, December 22.

Moulden, Dominic T. 2012. Interview with Liz Sablich. Washington, DC. April 28.

Moulden, Dominic T. and Gregory D. Squires. 2012. "Equitable Development Comes to DC.” Social Policy: Organizing for Social and Economic Justice. Fall, 42(3).

National Capital Revitalization Corporation. 2012. Accessed April 27, 2012. www. ncrcdc.com.

Neibauer, Michael. 2012. "With \$2.7M loan, D.C. aid to Progression Place Increases." Washington Business Journal, June 15.

Nelson, Arthur C. 2011. "The New California Dream: How Demographic and Economic Trends May Shape the Housing Market, A Land Use Scenario for 2020 and 2035." Urban Land Institute.

Office of the Deputy Mayor for Planning and Economic Development. 2012. "REQUEST FOR EXPRESSIONS OF INTEREST. Parcel 42.” April 20.

ONE DC Organizing Neighborhood Equity. 2012. Accessed April 27, 2012. http://www. onedconline.org/.

ONE DC Organizing Neighborhood Equity. 2013. "Performance Challenge.” Accessed March 14, 2013. http://www.onedconline.org/about-us-more-information-91/ transition-2006-more-information-89/32-performance.

ONE DC Organizing Neighborhood Equity. 2013. "Victories for ONE DC: The Marriott and Progression Place." Accessed March 14, 2013. http://www.onedconline. org/component/content/article/68-information/291-victories-for-one-dc-themarriott-and-progression-place-.

The Partnership for Working Families. 2012. "Community Benefits Agreements." Accessed April 27, 2012. http://communitybenefits.org/section.php?id=155.

People's District of D.C. 2011. "Willette on Taking Back Her Neighborhood.” January 14. http://peoplesdistrict.com/willette-on-taking-back-her-neighborhood.

Peters, Alan and Peter Fisher. 2004. "The Failures of Economic Development Incentives," Journal of the American Planning Association. 70(1): 27-37.

PolicyLink. 2013. Accessed March 1, 2013. www.policylink.org.

Sernovitz, Daniel J. 2012. “D.C.'s Progression Place on the Market.” Washington Business Journal, January 17.

United States Census Bureau. 2011. "American Community Survey 5-Year Estimates 2006-2010.” Accessed January 15, 2013. http://factfinder2.census.gov/faces/ nav/jsf/pages/searchresults.xhtml?refresh=t.

United States Census Bureau. 2000. Census 2000 Summary File 3. Accessed January 15, 2013. http://www.census.gov/census2000/sumfile3.html.

Warner, Sam Bass. 1987. The Private City: Philadelphia in Three Periods of its Growth. University of Pennsylvania Press; 2nd edition.

Wiener, Aaron. 2012. "Photos: The Progress at Progression Place." Washington City Paper, November 20. Accessed January 15, 2013. http://www.washingtoncitypaper.com/blogs/housingcomplex/2012/11/20/photos-the-progress-at-progression-place/.

Wilson, Amanda. 2012. "Six Developers Invited to Present Plans for Parcel 42." DC Mud, October 26. Accessed January 15, 2013. http://dcmud.blogspot.com/2012/10/ six-developers-invited-to-present-plans.html. 
Liz Sablich is a second year Master of Public Policy student at The George Washington University, concentrating in urban and community development policy. She received her BS in advertising from the.40797ppersitib.9f fllinois in 2008. Ms. Sablich is passionate about equitable public poli cy and the importance of utilizing strategic communication to inform and involve the American people in the policymaking process.

The author thanks Max Bentovim, Hasan Bhatty, Kristin Hubing and Anne Berry for their support and valuable, thoughtful feedback throughout the editing of this paper. She also thanks Professor Gregory Squires for teaching a thought-provoking course that ultimately led to this paper, and for his encouragement and feedback throughout the writing process. The author also thanks Mr. Dominic Moulden for his contributions to this paper and to the community. 